\title{
SiC-particulate aluminum composite foams produced from powder compacts: foaming and compression behavior
}

\author{
M. GUDEN* \\ Department of Mechanical Engineering, Izmir Institute of Technology, Gulbahce Köyu, Urla, \\ Izmir, TURKEY; Center for Materials Research, Izmir Institute of Technology, Gulbahce Köyu, \\ Urla, Izmir, TURKEY \\ E-mail: mustafaguden@iyte.edu.tr \\ S. YÜKSEL \\ Department of Mechanical Engineering, Izmir Institute of Technology, Gulbahce Köyu, Urla, \\ Izmir, TURKEY
}

Published online: 7 June 2006

The foaming behavior of $\mathrm{SiC}$-particulate $\left(\mathrm{SiC}_{\mathrm{p}}\right)$ aluminum composite powder compacts containing titanium hydride blowing agent was investigated by heating to $750^{\circ} \mathrm{C}$ in a pre-heated furnace. Aluminum powder compacts were also prepared and foamed using similar compaction and foaming parameters in order to determine the effect of $\mathrm{SiC}_{\mathrm{p}}$-addition on the foaming and compression behavior. The $\mathrm{SiC}_{\mathrm{p}}$-addition (10 wt\%) was found to increase the linear expansion of the Al powder compacts presumably by increasing the surface as well as the bulk viscosities. The compression tests conducted on $\mathrm{Al}$ and 10 and $20 \% \mathrm{SiC}_{\mathrm{p}}$ foams further showed a more brittle compression behavior of $\mathrm{SiC}_{\mathrm{p}} / \mathrm{Al}$ foams as compared with $\mathrm{Al}$ foams. The collapse stresses of $\mathrm{Al}$ and $10 \% \mathrm{SiC}_{\mathrm{p}} / \mathrm{Al}$ foams were also predicted using the equations developed for the open and closed cell foams. Predictions have shown that Al foam samples behaved similar to open cell foams, while $10 \% \mathrm{SiC}_{\mathrm{p}} / \mathrm{Al}$ foam collapse stress values were found between those of open and closed cell foams, biasing towards those of the open cell foams. (C) 2006 Springer Science + Business Media, Inc.

\section{Introduction}

Aluminum (Al) foams of closed and open cells are materials of increasing importance since they have good energy absorption capabilities combined with good thermal and acoustic properties. Reviews of many investigations on Al metal foam manufacturing and mechanical properties can be found in Refs. [1, 2]. Al foams can convert much of the impact energy into plastic energy and absorb much more energy than bulk metals at relatively low stresses. It has also been shown that when tubular metallic structures are filled with light weight $\mathrm{Al}$ closed cell foams; there exists an interaction effect between tube wall and foam filler [36 ]. The crushing loads of foam filled tubes are therefore found to be higher than the sum of the crushing loads of foam (alone) and tube (alone) mainly due to this effect. It was further shown that there was a critical total tube mass and the corresponding critical foam density and/or plateau stress above which the use of foam filling becomes more efficient than empty tube $[6,7]$. Therefore, the foams of higher plateau stresses should be preferred in foam filling applications over the foams of lower plateau stresses at similar densities, when the efficiency is considered. This may be achieved by adding ceramic particles and/or whiskers to the foamed metal microstructure similar to the metal matrix composite matrices.

Al closed-cell foams are currently manufactured by several different processes in which the liquid foam is stabilized by the addition of ceramic particles to the liquid metal either in-situ or ex-situ. In a process patented by Alcan International Limited, the liquid metal is foamed by 


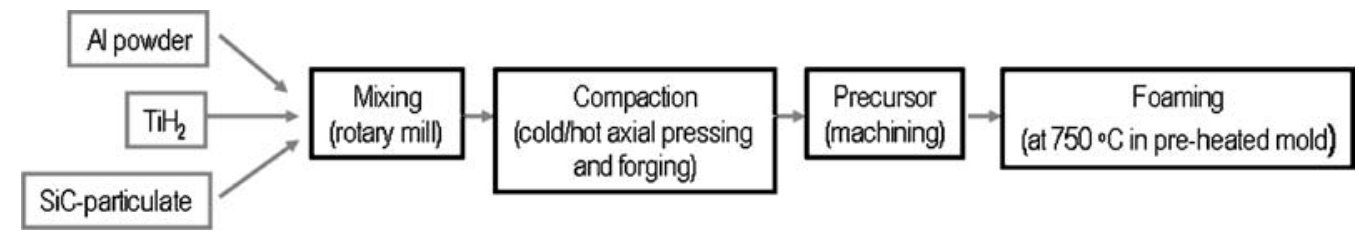

Figure 1 The processing stages of the foaming from powder compact process used.

injecting gases (e.g. air or nitrogen) into the melt [8] and the liquid foam is stabilized by adding $8-20 \mu \mathrm{m}$ size $\mathrm{SiC}$ particles [9]. In the Alporas process, developed in Japan, a blowing agent $\left(\mathrm{TiH}_{2}\right)$, which is added into the melt, decomposes and releases hydrogen gas into the melt, resulting in the expansion. The viscosity of the liquid metal is adjusted by calcium addition into the melt which results in formation of oxide particles by internal oxidation [10]. Foaming of powder compact process, patented by Fraunhofer CMAM, starts with mixing and compaction of metal powders with a blowing agent in order to form a foamable precursor material [11]. Heating of the precursor to or above the melting temperature results in decomposition of blowing agent and simultaneously expansion of the precursor. In this process, foam stabilization was ascribed to the metal oxide filaments which are remnants of the thin oxide layer on the aluminum powders and/or the solid component of the particular alloy (Al-rich phase in the Al-Si eutectic) $[9,12]$. In the Formgrip process, a passivated blowing agent is directly incorporated into the liquid metal, which is subsequently cast to obtain a foamable precursor [13]. The precursor is heated to an elevated temperature in order to drive the decomposition reaction of the blowing agent. The foamable precursor in the Formgrip process is a $\mathrm{SiC}$-particulate $\left(\mathrm{SiC}_{\mathrm{p}}\right)$ metal matrix composite (MMC) [13].

The effects of ceramic particle addition on the liquid foam stabilization and the foaming of the liquid metal in the foaming from liquid metal processes (Alcan and Alporas) have been widely investigated and suitable particle size ranges and concentrations for efficient foam stabilization have also been proposed [8, 14-19]. It has been recently shown that the ceramic particle addition $\left(\mathrm{TiB}_{2}\right)$ to the $\mathrm{Al}$ powder compacts in the foaming from powder compact process, although, increased the plateau stresses of $\mathrm{Al}$ foams, it was not effective in long-term foam stabilization [20]. Contrary to $\mathrm{TiB}_{2}$-addition, $\mathrm{SiC}_{\mathrm{p}}$-addition of $3 \%$ was shown to improve the foam stability of Al powder compacts [21]. The present report is a further investigation of the effect of $\mathrm{SiC}_{\mathrm{p}}$ addition on the foaming and quasi-static crushing behavior of $\mathrm{Al}$ powder compacts. For that purpose, $\mathrm{SiC}_{\mathrm{p}} / \mathrm{Al} \mathrm{MMC}$ and $\mathrm{Al}$ powder compacts were prepared and foamed. The effect of $\mathrm{SiC}_{\mathrm{p}}$-addition on the foaming behavior was determined by comparing the expansions of the $\mathrm{SiC}_{\mathrm{p}} / \mathrm{Al}$ and $\mathrm{Al}$ compacts processed under the same conditions. Compression testing on the prepared composite and $\mathrm{Al}$ foams was conducted in order to determine the effect of $\mathrm{SiC}_{\mathrm{p}}$-addition on the crushing behavior.

\section{Materials and experimental methods}

Aluminum closed cell foams were prepared using the foaming from powder compacts (precursors) process, patented by Fraunhofer CMAM [11]. The process started with the mixing of appropriate amounts of basic ingredients, $\mathrm{Al}$ powder, $\mathrm{SiC}_{\mathrm{p}}\left(10\right.$ and $20 \mathrm{wt} \%$ ) and $\mathrm{TiH}_{2}(1 \mathrm{wt} \%)$, inside a plastic container, which was rotated on a rotary mill in order to form a homogeneous powder mixture (Fig. 1). The average particle sizes of the $\mathrm{Al}$ and $\mathrm{SiC}_{\mathrm{p}}$ were 34.64 and $22.36 \mu \mathrm{m}$, respectively and the size of $\mathrm{TiH}_{2}$ particles was less than $37 \mu \mathrm{m}$. The specification of raw materials used is given elsewhere [22]. The foam expansion experiments were conducted using relatively small size cylindrical precursors, $27 \mathrm{~mm}$ in diameter and $9.5 \mathrm{~mm}$ in length while the foam samples for compression testing were prepared using plate-like precursors with sizes of $70 \times 70 \times 8 \mathrm{~mm}$.

In the foam expansion experiments, $\mathrm{Al}$ and $10 \mathrm{wt} \%$ $\mathrm{SiC}_{\mathrm{p}} / \mathrm{Al} \mathrm{MMC}$ compacts were prepared inside a stainless steel die by hot compaction at $350^{\circ} \mathrm{C}$ for $30 \mathrm{~min}$ under a pressure of $220 \mathrm{MPa}$. The cold compacts were then inserted into a pre-heated furnace at a temperature of $750^{\circ} \mathrm{C}$ inside a steel tube having the same diameter as the compact and a length of $80 \mathrm{~mm}$. The steel tube was tightly closed at the bottom and placed vertically into the furnace so that expansion was limited to only the vertical direction. Inserting and removing specimen took less than $10 \mathrm{sec}$. Foamed or partially foamed compacts were taken from the furnace after a specified furnace-holding time and then quickly cooled on a large steel plate by spraying water onto the steel tube. Foam sample heights were measured in order to calculate linear expansion (LE) using the following relation:

$$
L E=\frac{h_{f}-h_{o}}{h_{o}}
$$

where $h_{f}$ and $h_{o}$ are the height of the foam measured after a specific furnace holding time and initial height of the foamed compact, respectively. In few experiments the temperature of the foaming compact was measured during 


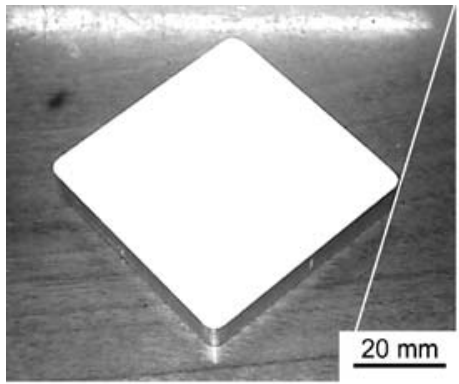

(a)

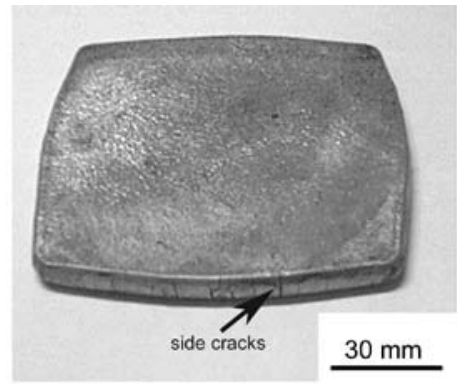

(b)

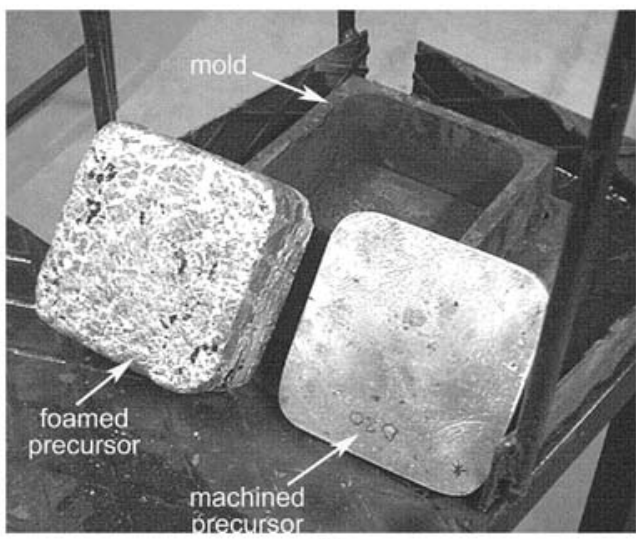

(c)

Figure 2 (a) cold compacted precursor, (b) precursor afted hot-forging and (c) machined and foamed precursor.

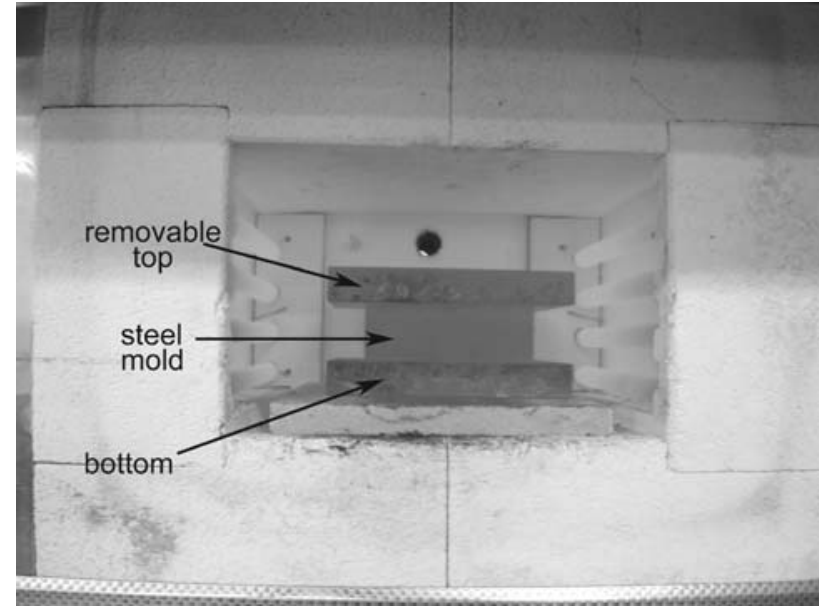

Figure 3 Foaming in the furnace with a steel mold closed at the top and bottom.

foaming using a thermocouple which made an intimate contact with the compact. The detailed information about the compact preparation, foaming and liner expansion measurements were given in Ref. [22].

In the second group of experiments, the powder mixture was initially cold compacted inside a steel die, $70 \times$ $70 \mathrm{~mm}$ in cross-section, under a pressure of $200 \mathrm{MPa}$. The compacts having $80 \%$ relative density (Fig. 2a) were then open-die hot-forged at a temperature of $350^{\circ} \mathrm{C}$, resulting in foamable precursor materials with the final densities of
$98 \%$ and thicknesses of approximately $8 \mathrm{~mm}$ (Fig. 2b). As a result of open die forging, the cross-sectional area of the precursor increased and small cracks were formed at the edges of the precursor. In order to remove the cracks, the cross-sectional area of hot-forged precursor was machined into the dimensions of $70 \times 70 \mathrm{~mm}$, same with the crosssectional dimensions of the foaming molds (Fig. 2c). The flat side surfaces of the precursor also provided good thermal contact with the foaming mold. Foaming experiments were conducted in a pre-heated furnace at a temperature of $750^{\circ} \mathrm{C}$. The precursor was inserted into a pre-heated steel mold providing expansion only in the vertical direction (Fig. 3). After precursor insertion, the steel mold (closed at the bottom) was closed at the top (Fig. 3). Inserting and removing specimen took less than $10 \mathrm{sec}$. The precursor started to expand after $5 \mathrm{~min}$ and filled the die completely at about $7 \mathrm{~min}$. In order to prepare $\mathrm{Al}$ foams of different densities, the steel mold accommodating the foamed precursor was taken from the furnace after holding times between 5 and $10 \mathrm{~min}$ and then water-quenched. Cylindrical compression test specimens, $25 \mathrm{~mm}$ in diameter and $30 \mathrm{~mm}$ in length, were core-drilled and then individually weighed and measured in order to calculate relative densities before compression testing. The relative density, $\rho^{*}$, is calculated as

$$
\rho^{*}=\frac{\rho_{f}}{\rho_{s}}
$$




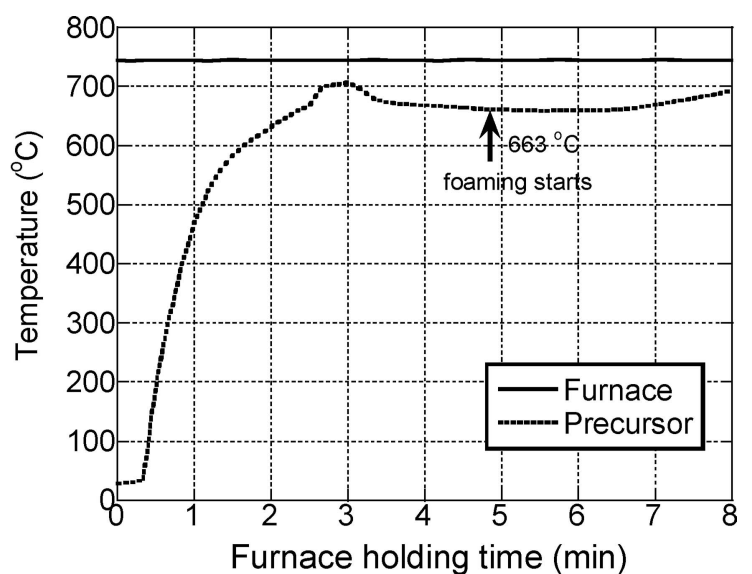

(a)

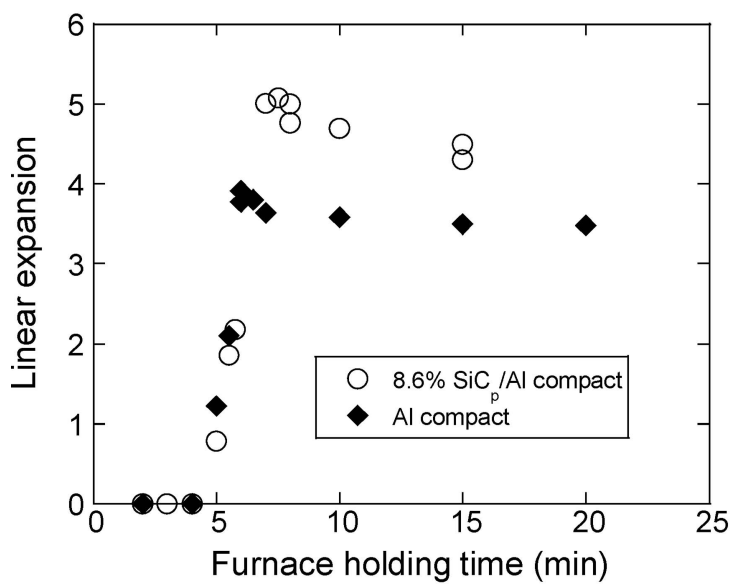

(b)

Figure 4 (a) precursor and furnace temperature $v s$. furnace holding time and (b) linear expansion vs. furnace holding time.

where $\rho_{f}$ and $\rho_{s}$ refer to the foam and bulk alloy densities, respectively. During core-drilling the pressure was kept as low as possible in order not to induce plastic deformation in the foam specimens. Core-drilling was conducted normal to the foaming direction i.e. through the thickness of the foam plate. Compression tests were conducted using a Schitmatzsu IG testing machine at a cross-head speed of $0.1 \mathrm{~mm} \mathrm{~s}^{-1}$. Larger rectangular foam samples $(5 \times 2 \times 3 \mathrm{~cm})$ were also compression tested and the deformations were video-recorded in order to observe the operative deformation mechanisms in-situ.

Deformed and undeformed foam samples were cut using electrical discharge machine and then mounted into epoxy for materiallographic examinations. Microstructural examinations were performed using optical microscopy and a Philips XL30-SFEG scanning electron microscope with an Energy Dispersive X-ray (EDX) analyzer. An image analyzing program was used to measure the average cell sizes of the foams.

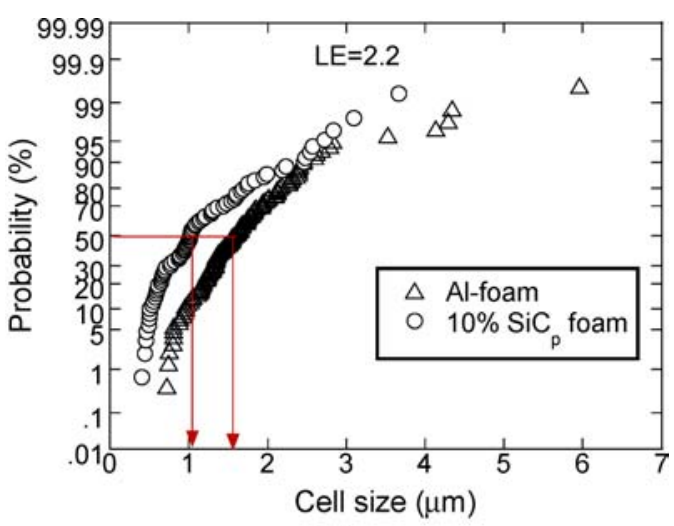

(a)

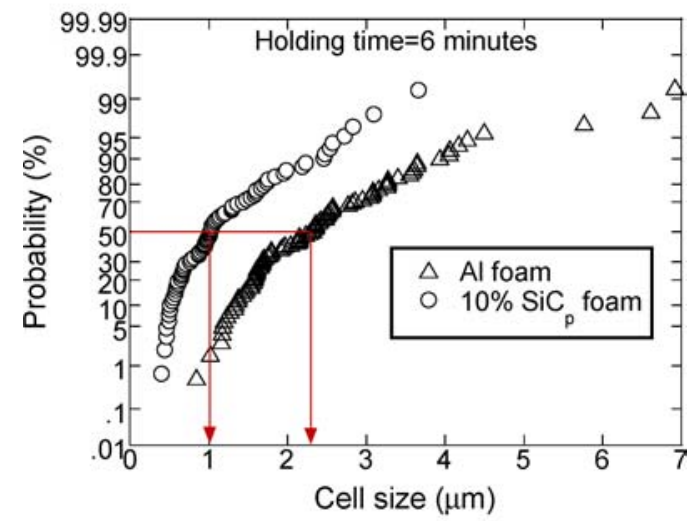

(b)

Figure 5 Probability $v$ s. cell size in $\mathrm{Al}$ and $10 \% \mathrm{SiC}_{\mathrm{p}} / \mathrm{Al}$ foam at constant (a) linear expansion and (b) furnace holding time.

\section{Results and discussions}

\subsection{Effect of $\mathrm{SiC}_{\mathrm{p}}$-addition on the foaming behavior}

Fig. 4a shows the variations of the precursor and furnace temperature as function of the furnace holding time. Although the temperature of the precursor rose to $663^{\circ} \mathrm{C}$ after 3 min (Fig. 4b), the expansion of the liquid precursor did not start until 5 min (Fig. 4b). The effect of $\mathrm{SiC}_{\mathrm{p}}$-addition on the foaming behavior of the compacts seen in Fig. 4b is to increase the linear expansion and hence increase the foam stability. It was further observed that the $\mathrm{SiC}_{\mathrm{p}}$-addition decreased the drainage of the liquid foam. Figs. 5a and $\mathrm{b}$ show the variation of cell size in $\mathrm{Al}$ and $\mathrm{SiC}_{\mathrm{p}} / \mathrm{Al}$ composite foam at a constant linear expansion of 2.2 and a constant furnace holding time of $6 \mathrm{~min}$. In both cases, the composite foam mean cell size calculated from the probability $v s$. cell size graphs of Figs. 5a and b, are smaller than that of $\mathrm{Al}$ foam, proving the slower rate of foam expansion in the composite compacts as compared with $\mathrm{Al}$ compacts. Present results of increased foam expansion and decreased extent of foam drainage with the $\mathrm{SiC}_{\mathrm{p}}$-addition were also agreed with the results of Kennedy and Asavavisitchai [20], who investigated the effect of various ceramic particle additions on 


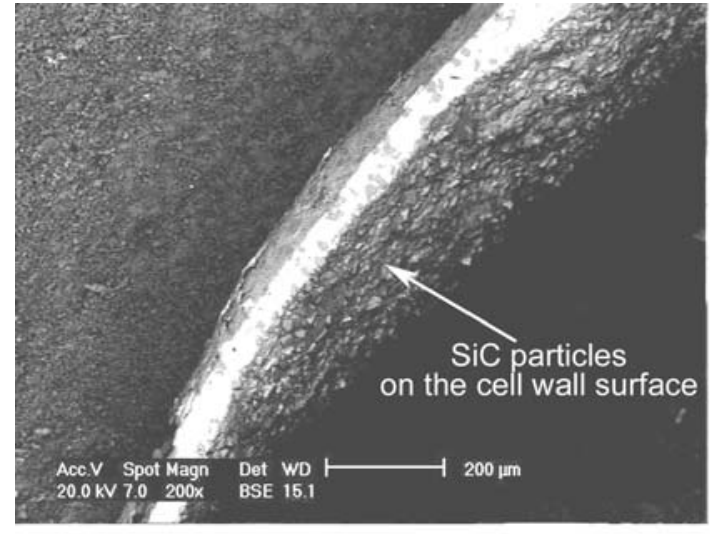

(a)

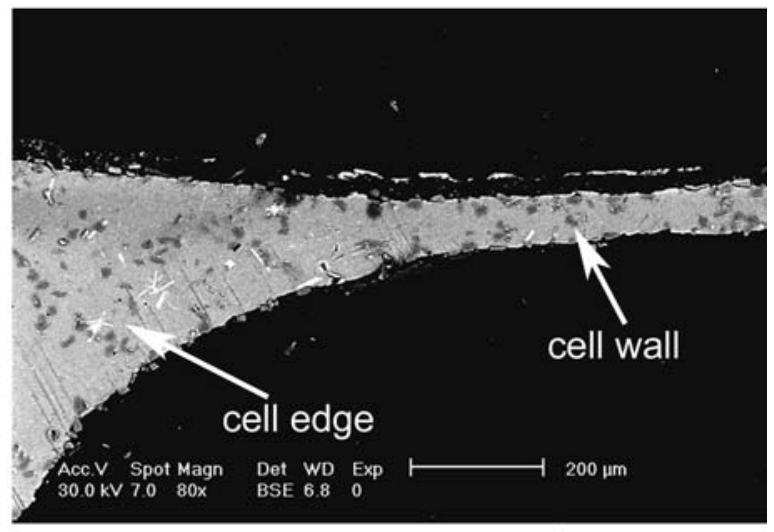

(b)

Figure $6 \mathrm{SEM}$ micrographs of $\mathrm{SiC}$ particles (a) on the cell wall surfaces and (b) interior of cell edge and cell wall of $10 \% \mathrm{SiC} / \mathrm{Al}$ foam.

the foam expansion and stability of Al powder compacts. Foam stabilization was ascribed to the metal oxide filaments which are remnants of the thin oxide layer on the aluminum powders and/or the solid component of the particular alloy $[9,12]$. The presence of solid particles plays a critical role in liquid foam stabilization through increasing melt bulk viscosity and contributing to increasing surface viscosity of the cell faces if a significant fraction of particles is located at the gas/melt interface. Both are effective in slowing down capillarity-driven melt flow from cell faces through cell edges (cell thinning) and gravity driven melt flow through cell edges (drainage) [13]. In the composite foam, the particles tended to segregate at the liquid/gas interface and were present inside the cell wall (Fig. 6a), similar to the $\mathrm{SiC}_{\mathrm{p}} / \mathrm{Al}$ foams produced by Alcan and Formgrip processes [13, 18, 23, 24]. This was attributed to the partial wetting of the $\mathrm{SiC}$ particles by liquid $\mathrm{Al}$ metal [18]. The good wetting of $\mathrm{SiC}$ particles by liquid $\mathrm{Al}$ was proposed to be a consequence of the reaction between liquid $\mathrm{Al}$ and $\mathrm{SiC}$, resulting in $\mathrm{Al}_{4} \mathrm{C}_{3}$ formation and the release of $\mathrm{Si}$ in to the melt [21]. The formation of $\mathrm{Al}_{4} \mathrm{C}_{3}$ phase at the $\mathrm{SiC}$ particle/Al metal interface and the release of $\mathrm{Si}$ into the melt were also detected in the prepared composite foams through EDX analysis [22]. In the case of non-wetting particle addition such as $\mathrm{TiB}_{2}$, although particle segregation at the liquid/gas interface was observed, the foam was not stabilized in long term [21]. Aside from particle segregation at the gas/melt interface, a small fraction of the particles was also found in the cell edges (Fig. 6b), proving the potential of the $\mathrm{SiC}_{\mathrm{p}}$ for the enhancement of the bulk and surface viscosities. The solid particles may also have a destabilizing effect if an unsuitable particle size is selected for viscosity enhancement, especially when the size of the particles is in the range of cell face thickness [25]. The higher solid content of the foamed composite compacts is believed to be responsible for the enhanced foaming behavior.

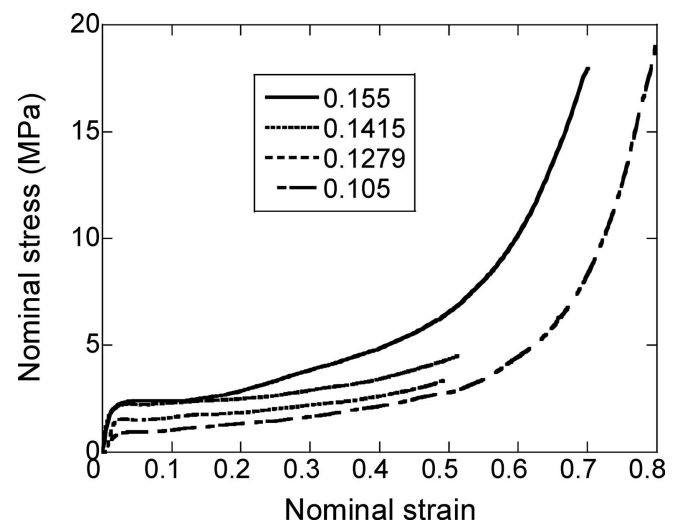

Figure 7 Compression stress-strain curves of $\mathrm{Al}$ foam at various relative densities.

\subsection{Effect of SiC-addition on the compression behavior}

Typical engineering compression stress-strain curves of $\mathrm{Al}$ foam samples of various relative densities are shown in Fig. 7. It is seen that the flow stress is a strong function of relative density and the curves show the typical shape which may be divided into three regions: (1) linear elastic region, (2) collapse or plateau region and finally, (3) a densification region in which the properties approach those of fully-dense alloy. In the collapse region the deformation is localized in a narrow region of the sample via cell wall buckling and/or tearing. The flow stress in the collapse region is also noted to increase as the strain increases. Fig. 8 shows the typical stress-strain curves of $10 \% \mathrm{SiC}_{\mathrm{p}} / \mathrm{Al}$ foams with different relative densities. Similar to $\mathrm{Al}$ foam samples, the flow stresses show a strong dependence on the relative density. Although $10 \% \mathrm{SiC}_{\mathrm{p}} / \mathrm{Al}$ foam samples showed higher plateau stresses as compared with $\mathrm{Al}$ foam samples, composite foams of $20 \% \mathrm{SiC}_{\mathrm{p}}$ showed a brittle compression behavior (Fig. 9). It is also seen in Fig. 9 that, stress oscillations occur in the collapse regions of 


\section{SYNTACTIC AND COMPOSITE FOAMS}

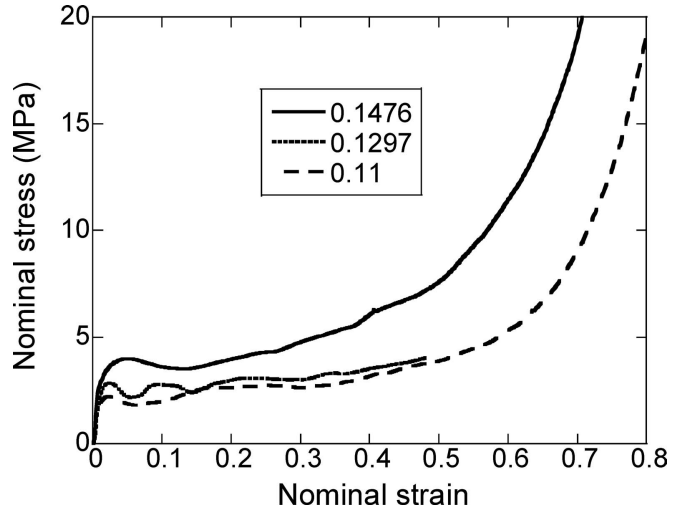

Figure 8 Compression stress-strain curves of $10 \% \mathrm{SiC}_{\mathrm{p}} / \mathrm{Al}$ foam at various relative densities.

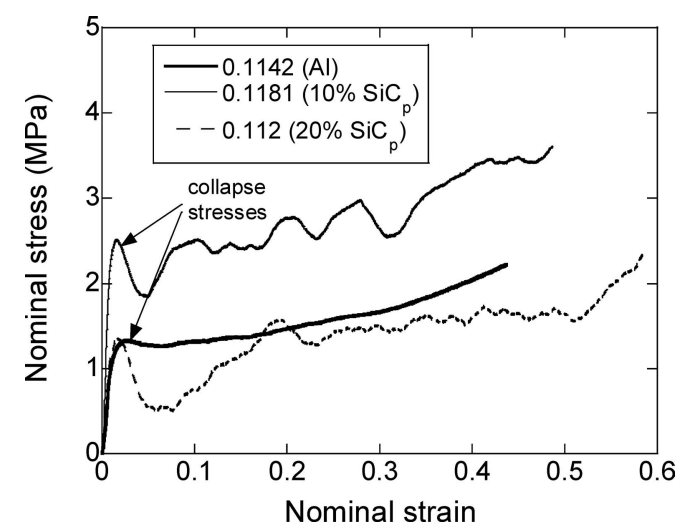

Figure 9 Comparison of compression stress-strain curves of $\mathrm{Al}$ and 10 and $20 \% \mathrm{SiC}_{\mathrm{p}} / \mathrm{Al}$ foams at similar relative densities.

the $\mathrm{SiC}_{\mathrm{p}} / \mathrm{Al}$ composite foams, while $\mathrm{Al}$ foams show an essentially monotonic increase in stress throughout the tests. The oscillations in stresses were found to be more pronounced in $20 \% \mathrm{SiC}_{\mathrm{p}} / \mathrm{Al}$ foam.

The micrographs of deformed $\mathrm{Al}$ and $10 \% \quad \mathrm{SiC}_{\mathrm{p}} / \mathrm{Al}$ foams as function percent strain are shown in Figs 10 and 11, respectively. Following the elastic region the deformation was localized in the regions marked with black arrows in Figs 10 and 11. It is also seen in the same figures that the deformation localization starts from the locations of the largest cell size or the lowest density (weakest link), marked with white arrows at $0 \%$ strains in Figs 10 and 11. The deformation localization then proceeded through the undeformed sections of the samples as the strain increased. Microscopic analyses of the localized regions have shown that the main deformation mechanism in both foams was the cell wall bending, i.e. cell edges buckled over cell walls (Figs 12a and b). It is also seen in Fig. 12b that the buckling of the cell walls in some occasions resulted in tearing of the cell walls (marked with white arrows). It was found that the incidence of cell wall tearing was higher in $10 \% \mathrm{SiC}_{\mathrm{p}} / \mathrm{Al}$ foam as compared with $\mathrm{Al}$ foam. Since the deformation mechanism in $\mathrm{Al}$ foam is mainly controlled by the cell wall bending rather than cell wall tearing, smooth and constantly rising stresses was observed [26]. In $10 \% \mathrm{SiC}_{\mathrm{p}} / \mathrm{Al}$ foam, the oscillations in the stress-strain curve were most likely due to the tearing of the cell walls. The effect of $\mathrm{SiC}$ particle on the cell wall tearing is clearly shown in Figs 13a and b. In Fig. 13a, the crack started on the cell wall surfaces is seen to follow the particle/metal interface and resulted in particle debonding (marked with arrow). Fig. 13b shows the particles located at cracks in a bent cell wall.

The deformation sequence of $20 \% \mathrm{SiC}_{\mathrm{p}} / \mathrm{Al}$ foam at various percent strains is shown in Fig. 14. In this foam, different from $\mathrm{Al}$ and $10 \% \mathrm{SiC}_{\mathrm{p}} / \mathrm{Al}$ foams, the deformation is completely controlled by the cell wall tearing. In brittle foams, the failure can be initiated from any pre-existing crack available in the structure and result in breaking of specimen into parts, therefore, strain hardening effect cannot occur [26]. It was also proposed although the local stresses within the broken foam parts increased, the integral stress calculated on the cross-section may even decrease [26]. The failure of the tested $20 \% \mathrm{SiC}_{\mathrm{p}} / \mathrm{Al}$ foam proceed in a localized form as depicted in Fig. 14 and small broken parts of samples observed during the tests proved partly the brittle deformation behavior. Figs 15ad clearly show the sequence of cell wall tearing in this foam. First, the bending of cell walls (Figs 15a and b) occurs, and then the bent cell walls rupture under the applied compressive load (Figs 15c and d).

Since the deformation mechanism of $\mathrm{Al}$ and $10 \%$ $\mathrm{SiC}_{\mathrm{p}} / \mathrm{Al}$ foam are very much similar, the compression

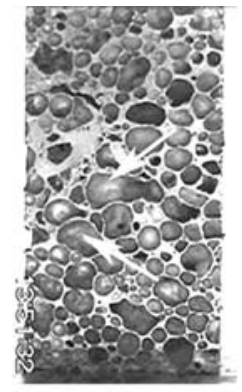

$0 \%$

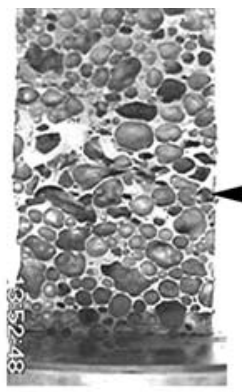

$11 \%$

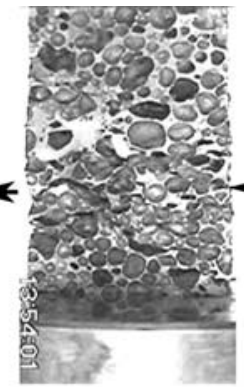

$22 \%$

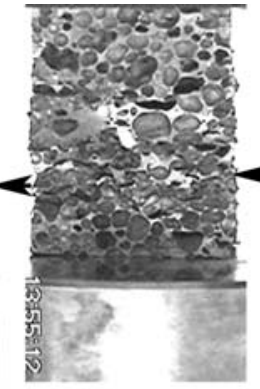

$33 \%$

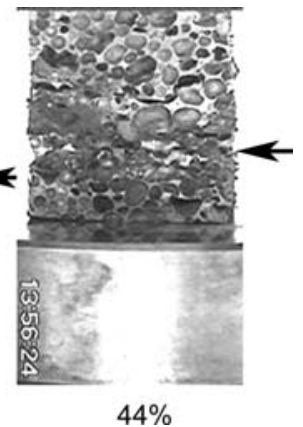

$44 \%$

Figure 10 The deforming $\mathrm{Al}$ foam sample at various percent strains. 


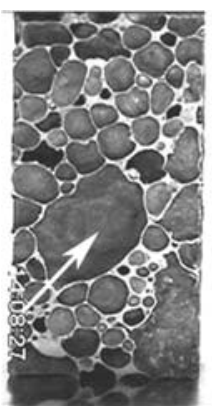

$0 \%$

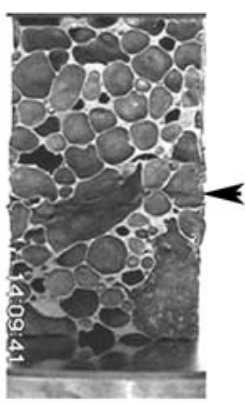

$11 \%$

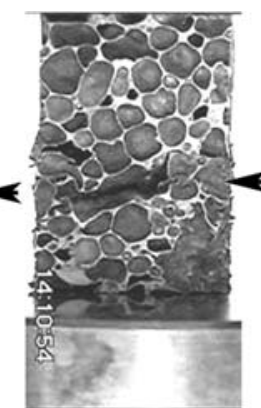

$22 \%$

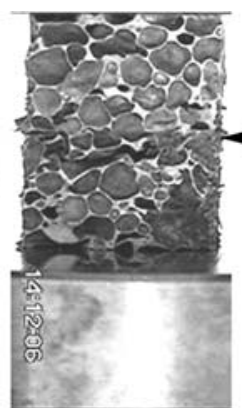

$33 \%$

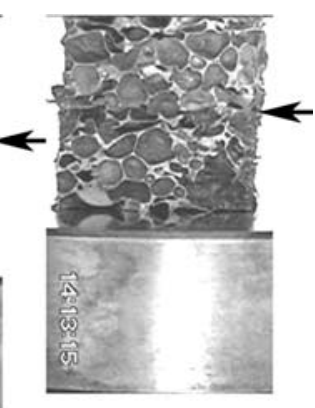

$44 \%$

Figure 11 The deforming $10 \% \mathrm{SiC}_{\mathrm{p}} / \mathrm{Al}$ foam sample at various percent strains.

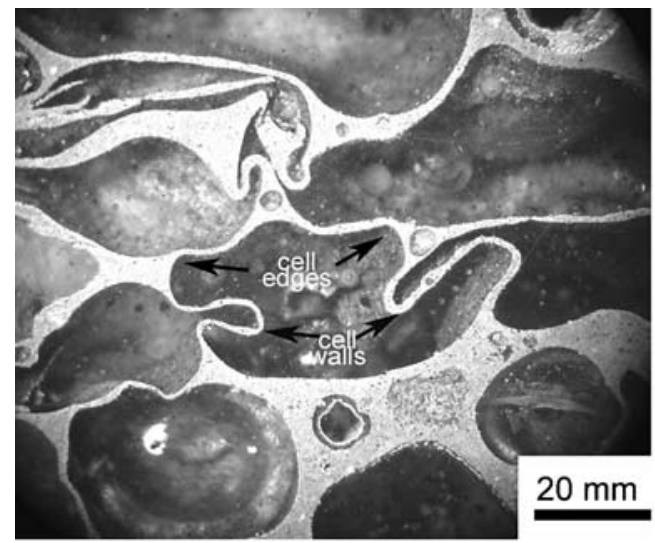

(a)

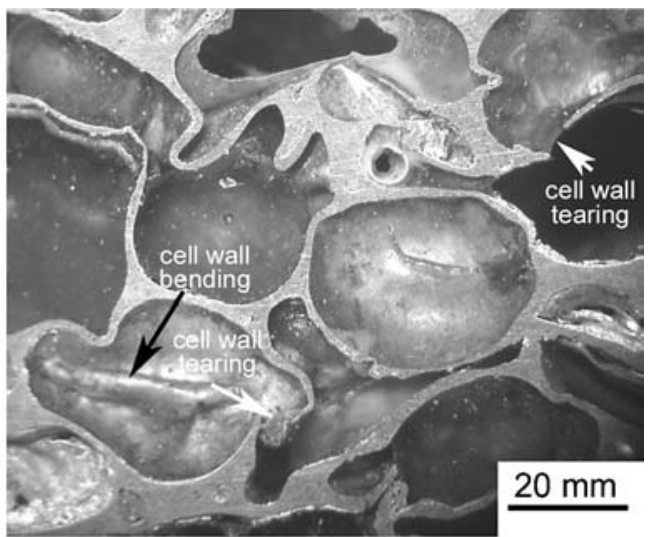

(b)

Figure 12 The deformed cell micrographs of (a) $\mathrm{Al}$ foam and (b) $10 \% \mathrm{SiC}_{\mathrm{p}} / \mathrm{Al}$ foam samples showing cell wall bending and tearing.

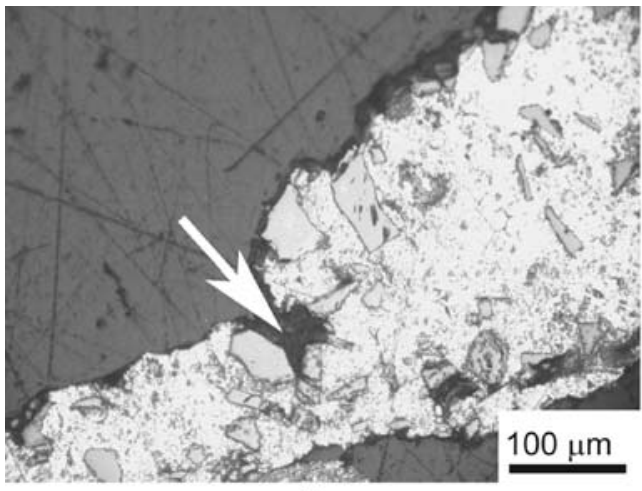

(a)

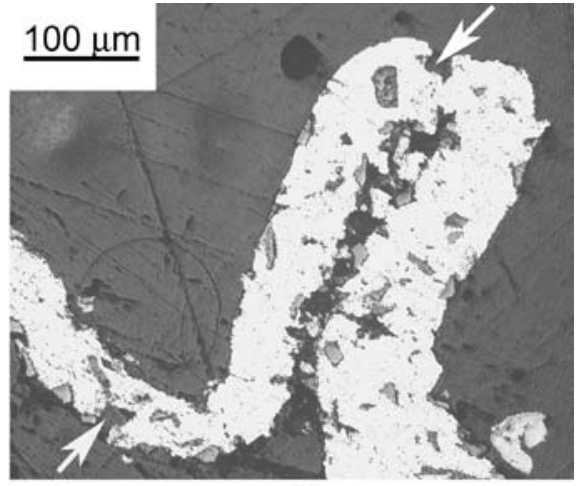

(b)

Figure 13 Development of cracks around the $\mathrm{SiC}$ particles (a) near to a cell edge and (b) on the bended cell walls of $10 \%$ SiC $/ \mathrm{Al}$ foam tested until about $50 \%$ strains.

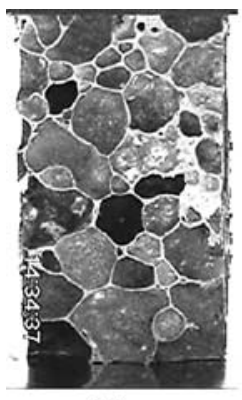

$0 \%$

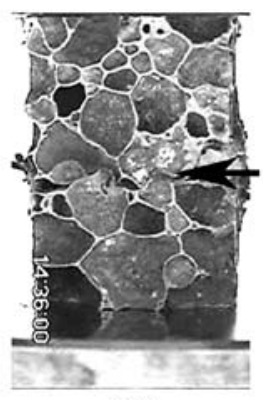

$14 \%$

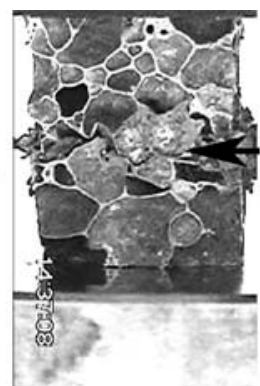

$28 \%$

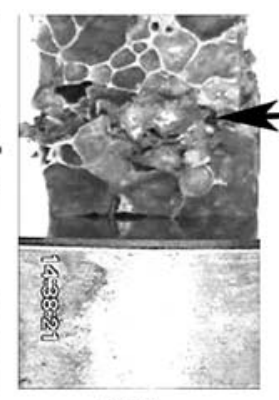

$42 \%$

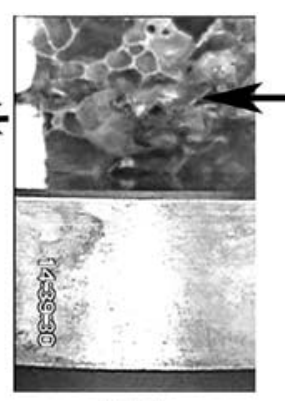

$56 \%$

Figure 14 The deforming $20 \% \mathrm{SiC}_{\mathrm{p}} / \mathrm{Al}$ foam sample at various percent strains. 


\section{SYNTACTIC AND COMPOSITE FOAMS}
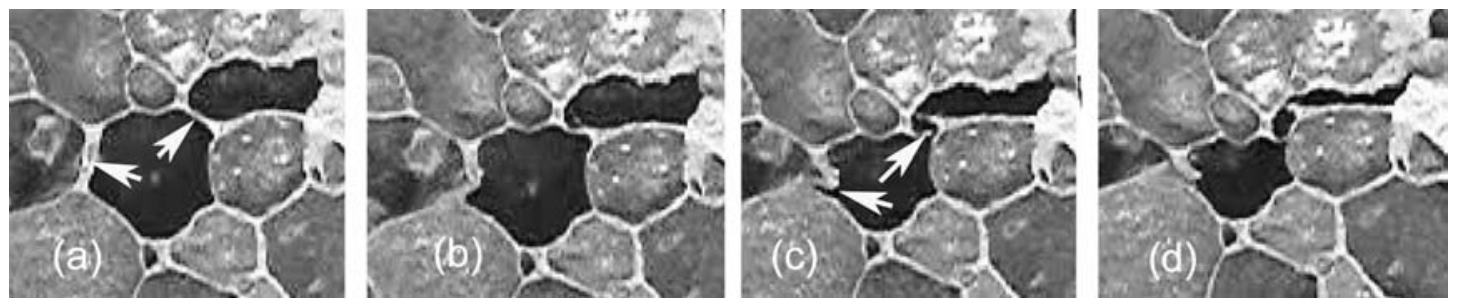

Figure 15 Montages of micrographs of cell wall rupture in a $20 \% \mathrm{SiC}_{\mathrm{p}} / \mathrm{Al}$ foam sample; (a) undeformed, (b) cell wall bending and (c) and (d) progressive cell wall rupture.

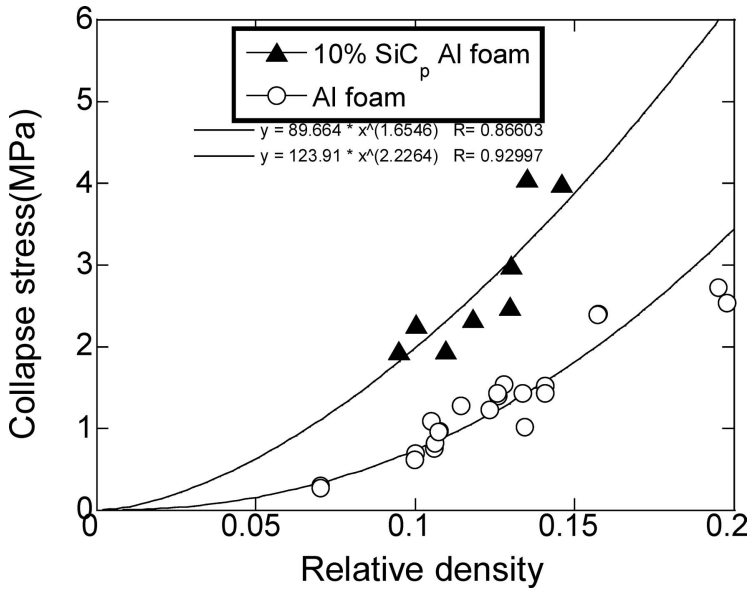

Figure 16 Fitting experimental collapse stresses to Eqn. 3.

behavior comparison will be made only between these foams. A general relationship relating the compressive strength mechanical properties of foams to their relative density, $\rho *$, has been previously proposed as [27]

$$
\frac{X_{s}}{X_{f}} \approx K \rho^{* n}
$$

where $X$ is a property such as the modulus or collapse stress, $f$ and $s$ refer to foam and dense solid respectively, and $K$ and $n$ are constants. Fitting Equation 2 with the experimental collapse stress (see Fig. 9) values gives $n$ values of 1.6 and 2.2 for $10 \% \mathrm{SiC}_{\mathrm{p}} / \mathrm{Al}$ and $\mathrm{Al}$ foams (Fig. 16), respectively. Somewhat similar values of $n$ were reported for the $\mathrm{Al}(2.489)$ and $10 \% \mathrm{TiB}_{2} / \mathrm{Al}(1.48)$ foams prepared by the same method. It is also noted that Equation 2 is developed for open cell foams. The following general equation has been proposed for the collapse stress of open and closed cell foams [28]:

$$
\frac{\sigma_{f}}{\sigma_{s}}=0.3\left(\phi \rho^{*}\right)^{\frac{3}{2}}+(1-\phi) \rho^{*}
$$

where $\phi$ is the volume fraction of the solids contained on the plateau borders. The first term in Equation 3 is due to bending and the second is due to membrane stretching. Equation 3 predicts the collapse stress values of open-cell foam when $\phi$ equals to 1 , and the collapse stresses of

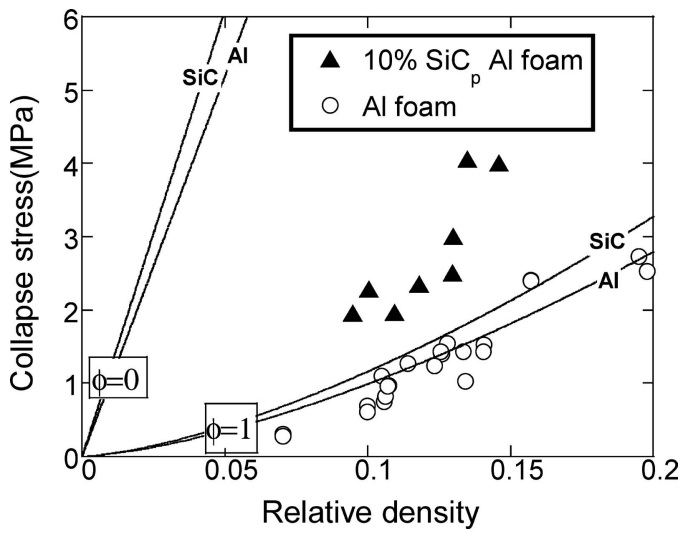

Figure 17 Fitting experimental plateau stresses of $\mathrm{Al}$ and $10 \% \mathrm{SiC}_{\mathrm{p}} / \mathrm{Al}$ foam to Eqn. 4, for $\phi$ values of 0 and 1.

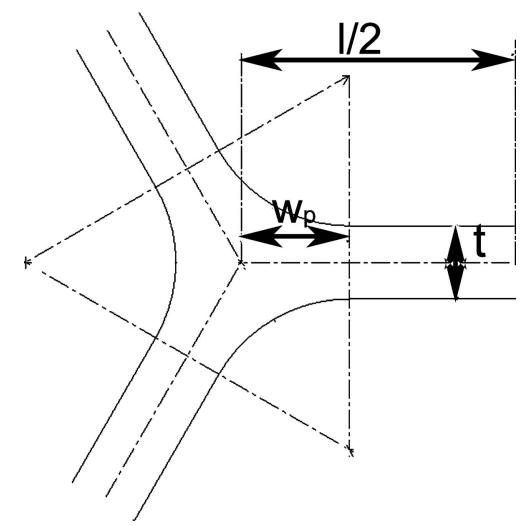

Figure 18 Geometry of the cross-section of a tetrakaidecahedral cell edge with plateau borders.

closed cell foam when $\phi$ value equals to 0 . It is noted that in both Equations 3 and 4, the foam's mechanical properties scale with the precursor alloy properties and $\phi$. Equation 4 was fitted with experimental collapse stress values of $\mathrm{Al}$ and $10 \% \mathrm{SiC}_{\mathrm{p}} / \mathrm{Al}$ foam with $\phi$ values of 1 and 0 , corresponding to open and closed cell foams and the results are shown in Fig. 17. It can be seen that present foam samples collapse stresses are much lower than those of closed cell foam while Al foam collapse stresses show good agreement with those of open cell foam. On the contrary, $10 \% \mathrm{SiC}_{\mathrm{p}} / \mathrm{Al}$ foam samples show higher collapse stresses than those of open cell foam. 


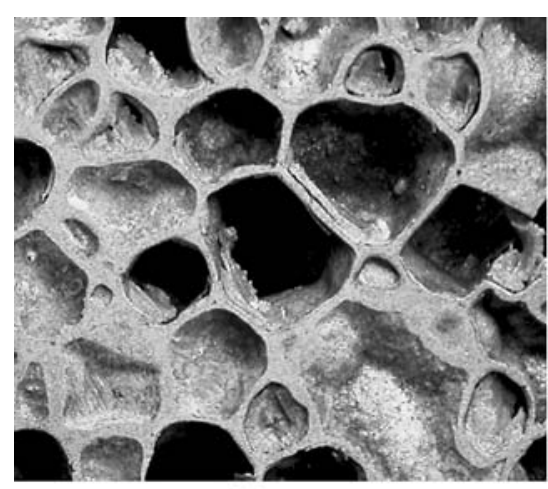

(a)

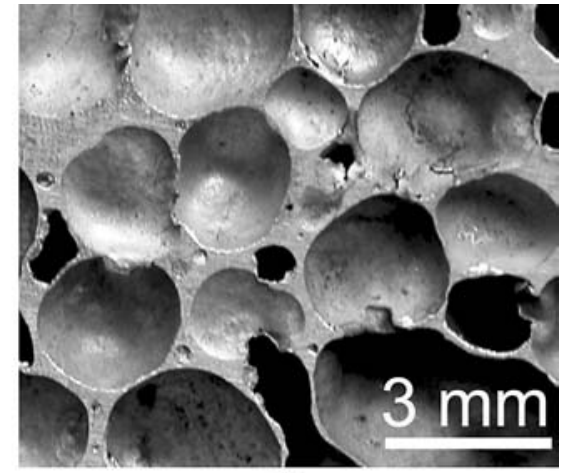

(b)

Figure 19 Optical micrographs showing cell morphologies in (a) $10 \% \mathrm{SiC}_{\mathrm{p}} / \mathrm{Al}$ foam and (b) $\mathrm{Al}$ foam at a relative density of approximately 0.13 .

The values of $\phi$ can be approximated using the following relation developed for the closed cell tetrakaidecahedral foam [29]:

$$
\phi=1-\frac{3 t\left(l-2 w_{p}\right)^{2}+6 t \sqrt{3}\left(l-(2 / \sqrt{3}) w_{p}\right)^{2}}{11.31 l^{3} \rho^{*}}
$$

where $l, w_{p}$, and $t$ are the cell wall length, plateau border thickness and cell wall thickness, respectively, as defined in Fig. 18. For a relative density of about 0.13 , the parameters of Equation 5 were calculated from the micrographs of the cross-sections of $\mathrm{Al}$ and $10 \% \mathrm{SiC}_{\mathrm{p}} / \mathrm{Al}$ foams shown in Fig. 19a and b. At least 20 measurements were taken for each parameter and the results were averaged. Following parameters were found; $t=0.05 \mathrm{~mm}$, $w_{p}=12.5 \mathrm{~mm}$ and $l=25 \mathrm{~mm}$ for $\mathrm{Al}$ foam sample and $t=0.15 \mathrm{~mm}, w_{p}=5 \mathrm{~mm}$ and $l=20 \mathrm{~mm}$ for $10 \%$ $\mathrm{SiC}_{\mathrm{p}} / \mathrm{Al}$ foam sample. The corresponding $\phi$ values were found approximately 0.95 and 0.8 for $\mathrm{Al}$ and $\mathrm{SiC}_{\mathrm{p}} / \mathrm{Al}$ foam, respectively. The foam material flow strength value in Equation 4 was further estimated via Vickers hardness tests on the polished cross-sections of the cell edges. In hardness testing of $\mathrm{SiC}_{\mathrm{p}} / \mathrm{Al}$ foam sample the indentations were performed in relatively $\mathrm{SiC}_{\mathrm{p}}$ free areas. The foam material average strength values were calculated 104 and $122 \mathrm{MPa}$ for $\mathrm{Al}$ and $\mathrm{SiC}_{\mathrm{p}} / \mathrm{Al}$ foam sample, respectively.

The collapse stresses for $\mathrm{Al}$ and $10 \% \mathrm{SiC}_{\mathrm{p}} / \mathrm{Al}$ foam were predicted using the above geometrical and material parameters and are shown in Fig. 20 together with experimental collapse stress values. Although estimated $\phi$ value gives the collapse stresses that agree with the experimental stresses of $\mathrm{SiC}_{\mathrm{p}} / \mathrm{Al}$ foam, it results in higher stress values than experimental values for $\mathrm{Al}$ foam. This also confirmed that $\mathrm{Al}$ foams behaved more or less as open cell foam due to significant amount of material found in the cell edges, while $\mathrm{SiC}_{\mathrm{p}} / \mathrm{Al}$ foam showed deviation from open cell foam since reduced amount of material segregation at the cell edges.

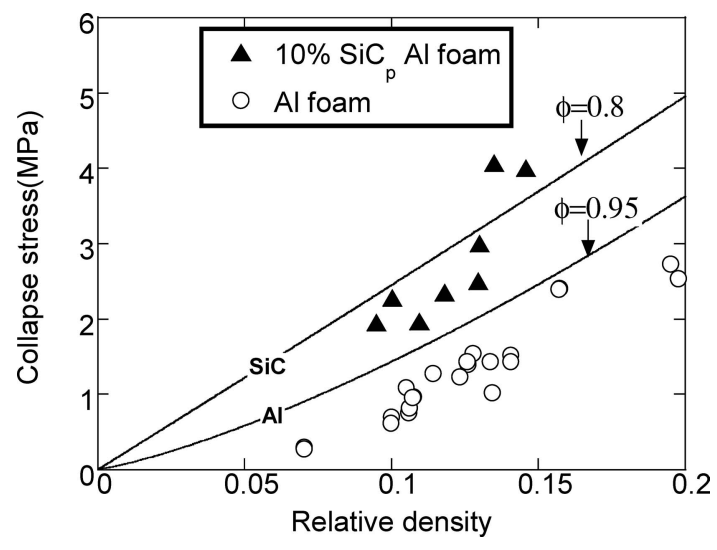

Figure 20 Fitting experimental plateau stresses of $\mathrm{Al}$ and $10 \% \mathrm{SiC}_{\mathrm{p}} / \mathrm{Al}$ foam to Eqn. 4, for experimentally determined $\phi$ values.

Present study has shown that although $\mathrm{SiC}_{\mathrm{p}}$-addition improved the foam expansion, it may have adverse effect on the foam compression behavior especially at increasing particle concentrations. The possible reasons of brittle nature of $\mathrm{SiC}_{\mathrm{p}} / \mathrm{Al}$ foams include the increased stress concentration at the particle/metal interface, the presence of brittle phase $\left(\mathrm{Al}_{4} \mathrm{C}_{3}\right)$ at the particle/metal interface and high stress concentrations in the regions of particle segregation. Detailed microscopic investigation will be conducted in another study.

The increased collapse stress of $10 \% \mathrm{SiC}_{\mathrm{p}} / \mathrm{Al}$ foams over $\mathrm{Al}$ foams may be partly due to the modification of the microstructure of the foamed $\mathrm{Al}$ metal, i.e. increased hardness of the foamed metal in composite foam and partly due to the modification of the cell morphology, i.e. reduced fraction of metal in the plateau borders. However, the calculations of foam plateau stresses based on the same yield strength of the foamed metal in $\mathrm{Al}$ and composite foams have shown that the latter effect was most likely explanation for the increased collapse stresses in the composite foam. 


\section{SYNTACTIC AND COMPOSITE FOAMS}

\section{Conclusions}

The $\mathrm{SiC}_{\mathrm{p}}$-addition (10\%) was found to increase the foam expansion of the $\mathrm{Al}$ powder compacts presumably by increasing surface as well as bulk viscosities. The compression tests conducted on $\mathrm{Al}$ and 10 and $20 \% \mathrm{SiC}_{\mathrm{p}} / \mathrm{Al}$ foams showed that $\mathrm{SiC}_{\mathrm{p}}$-addition induced a more brittle deformation behavior as compared with $\mathrm{Al}$ foams. Composite foams contained $20 \% \mathrm{SiC}_{\mathrm{p}}$ showed a complete brittle mode of deformation, mainly composing of cell wall tearing, while $10 \% \mathrm{SiC}_{\mathrm{p}} / \mathrm{Al}$ foam samples deformed predominantly by cell wall bending, very much similar to $\mathrm{Al}$ foam samples. The collapse stresses of $\mathrm{Al}$ and $10 \% \mathrm{SiC}_{\mathrm{p}} / \mathrm{Al}$ foams were also predicted using the equations developed for open and closed cell foams. This analysis showed that $\mathrm{Al}$ foam samples behaved similar to open cell foams, while $10 \% \mathrm{SiC}_{\mathrm{p}} / \mathrm{Al}$ foam collapse stress values were found between those of open and closed cell foams, biased towards those of the open cell foams.

\section{Acknowledgements}

The authors would like to thank the Scientific and Technical Council of Turkey (TUBITAK) for the grant \#MISAG-227.

\section{References}

1. J. BANHART, Progress in Materials Science 46 (2001) 559.

2. L. J. GIBSON, Annu. Rev. Mater. Sci. 30 (2000) 191.

3. S. SANTOSA, T. WIERZBICKI, A. G. HANSSEN and M. LANGSETH, Int. J. Impact Eng. 24 (2000) 509.

4. A. G. HANSSEN, M. LANGSETH and O. S. HOPPERSTAD, Int. J. Impact. Engng. 24 (2000) 475.

5. M. SEITZBERGER, F. G. RAMMERSTORFER, H. P. DEGISCHER and R. GRADINGER, Acta Mech. 125 (1997) 93.

6. M. GUDEN, A. K. TOKSOY and H. KAVI, Mater. Design. 27 (2006) 263.
7. S. SANTOS A and T. WIERZB ICK I, Comput. and Struct. 68 (1998) 343.

8. I. JIN, D. L. KENNY and H. SANG: US Patent No. 49733581990.

9. J. BANHART, J. Metals 12 (2000) 22.

10. T. MiYOShi, M. ITOH, S. AKIYAMA and A. KitAHARA, $A d v$. Eng. Materials 2 (2002) 179.

11. J. BAUMEISTER and H. SCHRADER, US Patent No. 5151246 (1992).

12. J. BANHART, Appl. Phys. Let. 78 (2001) 1.

13. V. GERGELY and B. CLYNE, Adv. Eng. Materials 2 (2002) 175 .

14. W. DEQING and S. ZIYUAN, Materials Science and Engineering A361 (2003) 45.

15. C. C. YANG and H. NAKAE, Journal of Materials Processing Technology 141 (2003) 202.

16. Z. SONG, J. ZHU, L. MA and D. HE, Materials Science and Engineering A298 (2001) 137.

17. L. MA and Z. SONG, Scripta Materialia 39 (1998) 1523.

18. S. W. IP, Y. WANG and J. M. TOGURI, Canadian Metallurgical Quarterly 38 (1999) 81.

19. N. BABCSAN, D. LEITLMEIER and H. P. DEGISCHER, Mat.wiss $u$. Werkstofftech 34 (2003) 22.

20. A. R. KENNEDY and S. AS AVAVIS ITCHA I, Scripta Materialia 50 (2004) 115.

21. A. R. KENNEDY and S. ASAVAVISITCHAI, Adv. Eng. Materials 6 (2004) 400.

22. S. ELBIR, S. YILMAZ, A. K. TOKSOY, M. GUDEN and I. W. HA LL, J. Mater. Sci. 38 (2003) 4745.

23. A. E. SiMONE and L. J. GiB S ON, Acta Mater. 46 (1998) 3109.

24. L. D. KENN Y, Materials Sci. Forum 217-222 (1996) 1883.

25. V. GERGELY, R. L. JONES and B. CLYNE, High Temperature Capillarity (HTC-200) (Kurashiki, Japan, 19-22 November 2000).

26. D. LEHMHUS and J. BANHART, Materials Science and Engineering A349 (2003) 98.

27. M. F. ASHBY, A. G. EVANS, J. W. HUTCHINSON and R. A. FLECK, Metal Foams: A Design Guide, Ultralight Metal Structure Conference, Brewster, MA (1998).

28. Y. SUGiMURA, J. MEYER, M. Y. HE, H. BART-SMith, J. GRENSTEDT and A. G. EVANS, Acta Mater. 45 (1997) 5245.

29. A. E. SimOne, L. GiBSOn and J. GiBSON, Acta Mater. 46 (1998) 2139. 